\title{
Karakteristik Trauma Siswa Sekolah Taman Kanak-kanak di Kecamatan Bandung Wetan Periode Agustus - Oktober 2016
}

\author{
Fairuz Primagita ${ }^{1}$, M. Rizal Chaidir², Putri Halleyana Adrikni Rahman ${ }^{3}$
}

${ }^{1}$ Fakultas Kedokteran Universitas Padjadjaran

\author{
${ }^{2}$ Departemen Ortopedi dan Traumatologi, Fakultas Kedokteran Universitas Padjadjaran/Rumah Sakit Umum \\ Pusat Dr. Hasan Sadikin, Bandung, Indonesia \\ ${ }^{3}$ Departemen Anatomi, Fisiologi dan Biologi Sel, Fakultas Kedokteran Universitas Padjadjaran/Rumah Sakit \\ Umum Pusat Dr. Hasan Sadikin, Bandung, Indonesia
}

\begin{abstract}
Abstrak
Berdasarkan World Report dari WHO pada tahun 2004, trauma pada anak cenderung mengalami kenaikan. Akibat yang ditimbulkan berupa cedera, disabilitas, kecacatan bahkan kematian. Di Indonesia, kasus terbanyak ditemukan pada anak usia 0-5 tahun (termasuk juga kelompok usia prasekolah). Penelitian ini bertujuan untuk mengetahui karakteristik trauma yang terjadi di sekolah taman kanak-kanak (TK) berupa jenis, penyebab dan kehadiran siswa pasca trauma. Penelitian ini dilakukan di kecamatan Bandung Wetan pada bulan Agustus hingga Oktober menggunakan metode deskriptif kuantitatif. Tiga TK dipilih sebagai objek penelitian. Data yang telah dikumpulkan merupakan data sekunder, berupa catatan kasus trauma di sekolah yang diperdalam menggunakan kuesioner dan wawancara kepada orang tua / pengasuh / guru dan disetujui perizinannya oleh pihak sekolah. Dari total 29 kasus trauma yang terjadi, 35\% kasus cedera kepala, 24\% kasus cedera ekstremitas juga luka dan 17\% cedera di wajah. Penyebab trauma, 48\% berkejar-kejaran dengan teman, 24\% antri wahana permainan, 14\% berkelahi dengan teman, dan dalam jumlah yang sama $7 \%$ dikarenakan bermain saat menunggu jemputan juga saat belajar. Tercatat $83 \%$ anak hadir setelah trauma dan $17 \%$ libur satu hari. Kasus trauma terbanyak yaitu cedera kepala. Penyebab terbanyak yaitu berkejar-kejaran dengan teman. Dari catatan kehadiran lebih dari $80 \%$ siswa hadir setelah mengalami trauma.
\end{abstract}

Kata Kunci : Anak TK, Sekolah, Trauma

\section{Characteristics of Injury on Kindergarten Students at Bandung Wetan District in August - October 2016}

\begin{abstract}
Based on World Report of World Health Organization (WHO) on 2004, the incidence of injury on children tends to increase. The impact of injury is disability, handicap and death. In Indonesia, the highest case was happened in age 0-5 years. The aimed of this study was to discover the characteristics of injury including type and causes of injury and student attendance post injury. This study was conducted at Bandung Wetan district on August to October used descriptive quantitative method. Three kindergartens were chosen as object of this study. Data was taken from children attendance at school and interview with parents/nanny/teacher. This study was approved by school committee. Of 29 injury cases, there were 35\% head injury, 24\% extremities injury and wound, $17 \%$ facial injury. According the causes of injury there were $48 \%$ romp with friend, $24 \%$ queued rides, $14 \%$ fight with friend, $7 \%$ playing while waiting for picked up also while studying in the classroom. There were $83 \%$ of the student who went to school post injury, but $17 \%$ of the student were absent for one day. The most type of injury is head injury. The most causes is romp with friend. More than $80 \%$ of student attend the kindergarten after experience injury
\end{abstract}

Keywords : Injury, Kindergarten student, School

Korespondensi:

Fairuz Primagita

Fakultas Kedokteran Universitas Padjadjaran

Jl. Raya Bandung-Sumedang KM 21 Jatinangor, Sumedang

Mobile : 085265185607

Email :fairuz.primagita@gmail.com 


\section{Pendahuluan}

Kasus trauma pada anak saat ini cendrung mengalami kenaikan dan menjadi masalah kesehatan masyarakat yang butuh perhatian khusus. ${ }^{1}$ World Report dari WHO tahun 2004 mencatat, angka kejadian trauma dan kekerasan pada anak mengakibatkan 950.000 kematian anak atau remaja dibawah 18 tahun. Dari angka tersebut, $\pm 90 \%$ kasus kematian disebabkan trauma yang tidak disengaja seperti kecelakaan, tenggelam, luka bakar, jatuh dan keracunan. Angka ini, meningkat rata-rata 3,4 kali di negara berkembang, termasuk Indonesia. ${ }^{2}$ Berdasarkan jenis trauma yang sering terjadi pada anak di negara berkembang, $58,5 \%$ kasus disebabkan jatuh. Dari jumlah tersebut 58,9\% kasus terjadi pada usia 4-12 tahun. $^{2}$ Merujuk klasifikasi usia anak dari CDC, pada usia ini anak dikategorikan menjadi anak usia prasekolah dan usia sekolah. Penyebab trauma pada kelompok usia ini pun bermacam macam. Tercatat $74,9 \%$ kasus terjadi saat anak bermain. ${ }^{2}$ Berdasarkan metode pembelajaran anak di sekolah, maka anak usia prasekolah memiliki peluang tinggi untuk mengalami trauma disebabkan metode belajar dengan bermain. ${ }^{3,4}$

Dalam penelitian sebelumnya sudah pernah ditemukan bahwa terdapat beberapa trauma yang terjadi pada kelompok usia prasekolah seperti cedera kepala, cedera wajah juga cedera ekstremitas. ${ }^{5,6}$ Hanya saja, penelitian yang dilakukan sebelumnya dikhususkan pada satu bentuk cedera saja. Penelitian lainnya juga menemukan bahwa anak sering mengalami trauma saat sedang bermain. ${ }^{2}$ tapi belum diketahui secara detail saat bermain seperti apa yang dapat menimbulkan trauma pada anak. Selain itu dalam World Report dari WHO diketahui bahwa $79 \%$ kasus trauma yang terjadi pada anak bisa langsung ditangani dan anak bisa pulang. ${ }^{2}$ Terkait trauma yang terjadi di sekolah pada anak usia prasekolah maka sesuai dengan informasi dari WHO tersebut akan terlihat pada gambaran kehadiran siswa di sekolah pasca trauma. Hingga saat ini belum ada penelitian yang mencari ketiga hal tersebut. Berdasarkan data kependudukan dari Badan Pusat Statistik, Bandung sebagai ibukota provinsi Jawa Barat ditempati seperlima dari penduduk Jawa Barat. Kota Bandung memiliki 30 kecamatan salah satunya Bandung Wetan. Di kecataman Bandung Wetan terdapat 16 sarana pendidikan untuk usia prasekolah berupa Taman Kanak-kanak (TK). ${ }^{7}$ Jumlah sarana pendidikan yang banyak ini menjadi pertimbangan untuk melakukan penelitian di Bandung Wetan. Penelitian ini bertujuan untuk mengetahui karakteristik trauma yang terjadi di sekolah TK khususnya di kecamatan Bandung Wetan berupa jenis trauma, penyebab trauma dan kehadiran siswa pasca trauma.

\section{Metode}

Penelitian ini merupakan bagian dari kegiatan penelitian yang dilakukan oleh Departemen Ortopaedi dan Traumatologi serta Departemen Anatomi, Fisiologi dan Biologi Sel Fakultas Kedokteran Universitas Padjadjaran. Penelitian ini menggunakan metode deskriptif kuantitatif dengan analisis cross sectional yang dilakukan pada sekolah taman kanak-kanak di kecamatan Bandung Wetan. Proses pemilihan sekolah yang menjadi objek penelitian dilakukan dengan metode simple random sampling.

Terdapat tiga sekolah yang diteliti pada penelitian ini yaitu TK Priangan, TK Istiqamah dan TK Taruna Bakti. Dari ketiga sekolah ini akan diambil data terkait kasus trauma yang pernah terjadi di sekolah. Data yang digunakan merupakan data sekunder yang diperoleh dari catatan sekolah mengenai kasus trauma yang pernah terjadi pada siswa dalam rentang tiga bulan penelitian ini dilakukan. Hasil catatan itu digali lebih lanjut menggunakan isian kuesioner8 dan wawancara yang dilakukan kepada orang tua/ pengasuh/guru. Data diambil sejak Agustus 2016 hingga Oktober 2016. Berdasarkan perhitungan jumlah sampel minimum yang dibutuhkan didapatkan angka 97. Tetapi untuk penelitian ini seluruh kasus yang terjadi dalam rentang bulan penelitian dilakukan diambil mempertimbangkan waktu penelitian yang cukup singkat sehingga belum bisa memenuhi sampel minimum yang ditargetkan. Data yang diambil terdiri dari jenis trauma, penyebab trauma dan kehadiran di sekolah pada anak tersebut. Data yang diperoleh diseleksi berdasarkan kriteria inklusi, yaitu anak usia 4-6 tahun yang bersekolah di taman kanak-kanak dengan arena bermain serta pernah mengalami trauma di sekolah dan kriteria ekslusi, yaitu anak yang pindah sekolah/tidak bisa di follow up.

Dalam melakukan penelitian ini, telah mendapatkan pembebasan etik dari Komisi Etik Fakultas Kedokteran Universitas Padjadjaran serta dilakukan perizininan ke BKBPM kota Bandung, Dinas Pendidikan Kota Bandung dan pihak sekolah taman kanak-kanak serta informed consent kepada orang tua/pengasuh/guru sebelum pengambilan data. Penelitian ini tidak mencantumkan identitas dari subjek sehingga menjaga privasi subjek penelitian. Tidak ada risiko yang ditimbulkan pada subjek penelitian. Analisis statistik pada penelitian ini menggunakan teknik statistik deskriptif dan disajikan dalam 
bentuk tabel, yaitu untuk melihat angka kejadian trauma, jenis kelamin, bentuk trauma, penyebab dan kehadiran siswa di sekolah.

\section{Hasil}

Dalam pengambilan data yang dilakukan selama tiga bulan, diperoleh 29 kasus trauma yang merupakan total kasus trauma yang pernah terjadi di sekolah dalam rentang waktu tiga bulan. Pada bulan pertama terdapat dua kasus anak dengan trauma di TK Priangan, empat kasus di TK Istiqamah, dan dua kasus di TK Taruna Bakti. Pada bulan kedua didapatkan dua kasus di TK Priangan, lima kasus di TK Istiqamah dan empat kasus di TK Taruna Bakti. Sementara pada bulan ketiga didapatkan tiga kasus di TK Priangan dan satu kasus di TK Taruna Bakti.

Pada tabel 1, perbandingan kasus trauma tiap sekolah berbanding total siswa di sekolah tersebut ditemukan kasus terbanyak terdapat di TK Priangan. Jumlah ini cukup tinggi dibandingkan dengan dua sekolah lainnya yaitu TK Istiqamah dan TK Taruna Bakti yang memiliki persentase kasus trauma yang lebih sedikit. Ini terjadi karena siswa di TK Priangan lebih sedikit dibandingkan dua TK lainnya. Sehingga proporsi perbandingan menjadi besar.

Berdasarkan tabel2, diketahuibahwa anak lakilaki lebih sering mengalami trauma dibandingkan anak perempuan. Sebagai penyebab terjadinya

\section{Tabel 1 Persebaran Kasus Trauma Berbanding Jumlah Siswa}

\begin{tabular}{llccc}
\hline Sekolah & $\mathrm{n}$ & \multicolumn{2}{c}{ Trauma } & \multirow{2}{*}{$\begin{array}{c}\text { \% Kasus } \\
\text { antar sekolah }\end{array}$} \\
\cline { 2 - 4 } & & Ya & Tidak & \\
\hline TK Priangan & 24 & $7(29,16 \%)$ & $17(70,84 \%)$ & $30,4 \%$ \\
TK Istiqamah & 154 & $9(6,20 \%)$ & $145(93,80 \%)$ & $39,2 \%$ \\
TK Taruna Bakti & 90 & $7(7,77 \%)$ & $83(92,23 \%)$ & $30,4 \%$ \\
Total & 268 & $23(8,58 \%)$ & $245(91,42 \%)$ & $100 \%$ \\
\hline
\end{tabular}

$\mathrm{n}=$ Total Siswa

Tabel 2 Persentase Karakteristik Trauma

\begin{tabular}{lcc}
\hline \multicolumn{1}{c}{ Variabel } & Jumlah & Presentase \\
\hline Jenis Kelamin & 17 & \\
Laki-laki & 6 & $74 \%$ \\
Perempuan & & $26 \%$ \\
Jenis Trauma & 10 & \\
Cedera Kepala & 5 & $35 \%$ \\
Cedera Wajah & 7 & $17 \%$ \\
Cedera di Ekstremitas & 7 & $24 \%$ \\
Luka & & $24 \%$ \\
Penyebab Trauma & 2 & $7 \%$ \\
Bermain Saat Menunggu Jemputan & 7 & $24 \%$ \\
Antri Wahana Permainan & 2 & $7 \%$ \\
Belajar di Kelas & 4 & $14 \%$ \\
Berkelahi dengan Teman & 14 & $48 \%$ \\
Berkejar-kejaran dengan Teman & & \\
Kehadiran Siswa di Sekolah Pasca Trauma & 19 & $83 \%$ \\
Hadir & 4 & $17 \%$ \\
Tidak Hadir & & \\
\hline
\end{tabular}


Tabel 3 Jenis Trauma yang Terjadi

\begin{tabular}{lccc}
\hline \multicolumn{1}{c}{ Jenis Trauma } & Jumlah & Persentase per Bagian & Persentase Total \\
\hline Cedera Kepala & & & \\
Benjol di Kepala & 8 & $80 \%$ & $28 \%$ \\
Memar di Kepala & 2 & $20 \%$ & $7 \%$ \\
Cedera Wajah & & & \\
Memar di Dahi & 5 & $100 \%$ & $17 \%$ \\
Cedera Ekstremitas & & & $7 \%$ \\
Memar di Tangan & 2 & $29 \%$ & $17 \%$ \\
Memar di Kaki & 5 & $71 \%$ & \\
Luka & 1 & $14 \%$ & $3,5 \%$ \\
Di Wajah & 1 & $14 \%$ & $3,5 \%$ \\
Di Tangan & 4 & $58 \%$ & $13,5 \%$ \\
Di Lutut & 1 & $14 \%$ & $3,5 \%$ \\
Di Betis & & & \\
\hline
\end{tabular}

trauma diketahui berkejar-kejaran dengan teman menjadi penyebab terbanyak. Diikuti antri saat ingin bermain di wahana permainan, berkelahi dengan teman dan bermain saat menunggu jemputan serta belajar di kelas dalam jumlah yang sama. Sedangkan pada akibat yang ditimbulkan dari kehadiran siswa pasca trauma lebih dari $80 \%$ anak hadir kesekolah meskipun terdapat $17 \%$ anak tidak hadir satu hari.

Tabel 3 menunjukkan jenis trauma yang terjadi, ditemukan benjol dikepala merupakan bentuk trauma paling sering terjadi pada anak di sekolah. Diikuti oleh memar di dahi ataupun di kaki dengan jumlah kasus yang sama. Dalam jumlah kecil yaitu satu kasus luka di wajah, tangan dan betis. Berdasarkan manifestasi yang terjadi diketahui bahwa memar menjadi manifestasi terbanyak pada trauma anak di sekolah taman kanak-kanak. Terdapat 14 kasus dengan manifestasi memar yang tersebar di daerah kepala, wajah, dan esktremitas.

\section{Pembahasan}

Anak menurut WHO didefinisikan sebagai orang dengan usia dibawah 19 tahun atau ketetapan umur tertentu sesuai negara masing-masing yang menjadikan standar usia dewasa menjadi lebih cepat. ${ }^{2}$ Berdasarkan kelompok usia anak menurut CDC dibedakan menjadi bayi (0-1 tahun), toddler (1-3 tahun), prasekolah (3-5 tahun), anak usia sekolah (6-11 tahun), remaja muda (12-14 tahun) dan remaja (15-17 tahun). Saat ini trauma pada anak telah menjadi salah satu masalah serius dalam kesehatan masyarakat. Trauma merupakan segala bentuk kekerasan yang menimpa tubuh sehingga terjadi kerusakan atau gangguan pada struktur dan fungsi jaringan atau organ tubuh yang terkena. Diketahui 950.000 kematian anak atau remaja dibawah 18 tahun disebabkan trauma dan $\pm 90 \%$ kasus ini merupakan trauma yang tidak disengaja seperti kecelakaan, tenggelam, luka bakar, jatuh dan keracunan menjadi penyebab trauma pada anak. ${ }^{1,29}$ Kecendrungan kasus pun berbeda di setiap negara, untuk negara berkembang kasus yang sering terjadi adalah jatuh yaitu sebanyak 913 anak. Angka ini disusul kecelakaan lalu lintas sebanyak 350 kasus. ${ }^{2,1}$

Berdasarkan tempat terjadinya trauma pada kelompok usia prasekolah kasus tertinggi terjadi di rumah yaitu sebanyak $55,9 \%$ disusul saat di jalan raya sebesar $21 \%$. Dari 913 kasus trauma yang disebabkan jatuh selain berlokasi di rumah terdapat dua tempat lain yang sering terjadi trauma yaitu bangunan publik (157 kasus) dan sekolah (96 kasus). ${ }^{2,1}$ Di sekolah khususnya kelompok usia prasekolah, anak diajar dengan metode belajar sambil bermain dan anak menghabiskan sekitar 4-5 jam di sekolah. ${ }^{3}$ Kegiatan belajar mengajar rata-rata dimulai di pagi hari yang merupakan waktu yang berisiko tinggi untuk terjadinya trauma. ${ }^{2}$ Tercatat 294 kasus trauma yang disebabkan jatuh terjadi pada pukul 06.00 hingga 12.00. disusul 203 kasus yang terjadi pada pukul 12.01 hingga 14.30 . Interval waktu ini dihabiskan anak di sekolah, sehingga ini meningkatkan kemungkinan terjadinya trauma di sekolah. ${ }^{2}$

Berdasarkan jenis kelamin World Report dari WHO, didapatkan hasil bahwa di Asia Tenggara terdapat 379 kasus trauma yang terjadi pada usia 
1-9 tahun dengan jenis kelamin laki-laki dan 200 kasus terjadi pada kelompok usia 1-9 tahun dengan jenis kelamin perempuan. Jumlah ini menunjukkan bahwa kasus trauma lebih sering terjadi pada kelompok jenis kelamin laki-laki. ${ }^{2}$ Selain itu dalam penelitian lainnya ditemukan juga bahwa laki-laki lebih sering mengalami trauma dibandingkan perempuan. ${ }^{5,9,1}$ Hal tersebut sesuai dengan penelitian ini bahwa $74 \%$ kasus trauma terjadi pada laki-laki dan $26 \%$ sisanya perempuan.

Trauma juga lebih sering terjadi pada saat anak bermain. Tercatat $74,9 \%$ terjadi saat anakanak sedang bermain. ${ }^{2}$ Saat berada di sekolah anak banyak bermain dengan teman sebayanya. ${ }^{10}$ Saat bermain anak biasanya berkejar-kejaran, berkelahi bahkan terjatuh. ${ }^{11}$ Hal ini sesuai dengan penelitian ini bahwa saat bermain anak lebih sering mengalami trauma baik saat berkejarkejaran, antri wahana permainan, berkelahi dengan teman.

Jatuh pada anak bisa menimbulkan berbagai manifestasi seperti benjol, memar, luka dan lain-lain. Dari 913 kasus trauma yang terjadi didapatkan 152 kasus memberikan manifestasi memar. $^{2}$ Dan dalam penelitian ini didapatkan 14 kasus memberikan manifestasi memar yang tersebar di berbagai bagian yaitu kepala, wajah, dan ekstremitas dan ini memberikan persentase terbesar terhadap jenis trauma yang terjadi di sekolah. Dalam penelitian ini juga, ditemukan bahwa bagian kepala adalah bagian yang sering mengalami trauma. ${ }^{12}$ Pada penelitian sebelumnya sudah pernah ditemukan beberapa jenis trauma yang terjadi pada anak usia prasekolah, hanya saja penelitian terdahulu fokus pada satu bentuk trauma saja seperti cedera kepala, cedera wajah ataupun cedera ekstremitas. ${ }^{5,6}$ Belum terdapat data pembanding untuk mendukung jenis trauma yang paling banyak terjadi pada anak usia TK.

Berdasarkan World Report dari WHO 79\% kasus trauma yang terjadi pada anak dapat langsung ditangani dan anak dapat langsung pulang. ${ }^{2}$ Terkait trauma yang terjadi di sekolah maka penilaian ini dilihat dari absensi siswa dan ditemukan $83 \%$ siswa hadir kesekolah setelah mengalami trauma dan $17 \%$ sisanya tidak hadir satu hari. Angka yang didapatkan ini tidak berbeda jauh dengan laporan dari WHO.

Keterbatasan dalam penelitian ini adalah waktu penelitian yang cukup singkat disebabkan hasil penelitian menjadi salah satu syarat kelulusan peneliti sehingga data yang didapatkan masih sedikit. Selain itu, bias informasi dapat terjadi pada penelitian ini seperti lupa, menyederhanakan ataupun membesar-besarkan kasus yang terjadi pada anak. Untuk mengatasi bias informasi tersebut maka peneliti mengkomunikasikan kepentingan penelitian ini dan informasi individu akan dirahasiakan agar lebih nyaman kepada subjek penelitian. Selain itu, kesesuaian informasi dari catatan pihak sekolah dan hasil wawancara juga diperhatikan. Sehingga informasi yang didapatkan peneliti lebih akurat.

Pada penelitian ini dapat disimpulkan bahwa trauma yang terjadi pada anak di sekolah merupakan masalah kesehatan masyarakat yang butuh perhatian khusus. Terdapat 8,58\% kasus terjadi pada anak usia TK di kecamatan Bandung Wetan. Dari jumlah tersebut bagian yang sering terkena yaitu kepala sebanyak 35\%. Manifestasi yang sering ditimbulkan adalah memar. Dan penyebab trauma tertinggi disebabkan berkejarkejaran dengan teman $48 \%$. Akibat pasca trauma tercatat $83 \%$ siswa bisa hadir ke sekolah, tapi $17 \%$ sisanya tidak hadir satu hari. Dibutuhkan kerjasama antara semua komponen yang terdapat di sekolah yaitu guru, orang tua dan siswa untuk bisa mencegah terjadinya kasus trauma di sekolah. Tindakan promotif dan preventif pun perlu dilakukan untuk mengurangi kasus trauma yang terjadi di sekolah seperti merancang sarana permainan yang aman untuk anak.

Kedepannya, diharapkan dilakukan penelitian lanjutan tentang hubungan jenis trauma dan penyebab terjadinya trauma di sekolah pada anak TK. Sehingga dapat diketahui keterkaitan jenis trauma yang terjadi dengan penyebab trauma agar langkah pencegahan yang dilakukan lebih tepat.

\section{Daftar Pustaka}

1. Atlı B, Eren ŞH, Coşkun A, Korkmaz I, Eren M. Evaluation of Pre-School (0-6) Age Group Trauma Patients Etiology. J Acad Emerg Med. 2014;152:37029.

2. Peden M, Oyegbite K. World report on child injury prevention World report on child injury prevention. WHO. 2008.

3. Bulunuz M. Teaching science through play in kindergarten: does integrated play and science instruction build understanding? Eur Early Child Educ Res J. 2013;21(2):226-49.

4. Arezes P, Baptista JS, Barroso MP, Carneiro P, Cordeiro P, Costa N, et al. Occupational Safety and Hygiene. 1st ed. Arezes, Pedro M. (University of Minho, Guimaraes P, editor. London: Taylor \& Francis; 2013.

5. Bregagnolo LA, Bregagnolo JC, Silveira F. Oral and Maxillofacial Trauma in Brazilian Children and Adolescents. Braz Dent J. 2013;24:397-401.

6. Chandra WD, Ismiarto YD, Tahid A, Hidajat NN. Cruris Fracture among Child Patients in Dr. Hasan Sadikin General Hospital 
Bandung. Althea Med J. 2015;2(October 2012):276-80.

7. Herlani. Profil Kecamatan Bandung Wetan Kota Bandung. 2015.

8. Knight KL. More precise classification of orthopaedic injury types and treatment will improve patient care. J Athl Train. 2008;43(2):117-8.

9. Kuschithawati $\mathrm{S}$, Magetsari $\mathrm{R}, \mathrm{Ng} \mathrm{N}$. Faktor risiko terjadinya cedera pada anak usia sekolah dasar. Dinas Kesehatan Kota Yogyakarta, Yogyakarta. 2007;23(3):131-41.

10. Cohen DD, Correa-bautista JE, Ramírezvélez R, González SA, Sarmiento OL, Cohen DD, et al. Results From Colombia's 2014 Report Card on Physical Activity for
Children and Youth Results From Colombia's 2014 Report Card on Physical Activity for Children and Youth. J Phys Act Health. 2014;11(May):S33-44.

11. Pyle A, Danniels E. A Continuum of PlayBased Learning: The Role of the Teacher in Play-Based Pedagogy and the Fear of Hijacking Play. Early Educ Dev. 2016;1-16.

12. Sultan Alhabdan, Mohammed Zamakhshary, Manal AlNaimi, Hala Mandora MA, Khalid Al-Bedah, Salem Al-Enazi AA$\mathrm{H}$. Epidemiology of traumatic head injury in children and adolescents in a major trauma center in Saudi Arabia: implications for injury prevention. Ann Saudi Med. 2013;33(1):2013. 